\title{
Personal and Work Related Correlates of Professional Self-Efficacy of Teachers in the Bachelor in Industrial Technology Program of the Bulacan State University
}

\section{Allen N. Maroma ${ }^{1}$ and Dolly P. Maroma ${ }^{2}$}

${ }^{1}$ College of Industrial Technology Bulacan State University, City of Malolos Bulacan, Philippines, 3000

${ }^{2}$ Dean, College of Industrial Technology Bulacan State University, City of Malolos Bulacan, Philippines, 3000

\begin{abstract}
Background/Objectives: The study aimed to the professional self-efficacy levels of Industrial Technology teachers and determine how personal and work-related factors correlate to this. Methods/Statistical analysis: Questionnaires were administered to the respondents who were purposively chosen for this research. Demographic data were taken as personal-related factors, while facilities and equipment, program culture an administrative support and professional organization were considered as indicators of work-related factors. Findings: To discern professional efficacy, knowledge improvement, attitudes and practices were taken into account as indicators. Findings showed that Work related variables are predominantly significantly related to professional efficacy rather than personal-related variables. Program culture has positive significant correlation with knowledge improvement as an indicator of professional efficacy. Improvements/Applications: Administrative support and program culture have positive significant correlation with attitude as an indicator of professional efficacy.. Hence, it was concluded that work-related rather than personal-related factors had significantly influenced teachers' perception of professional self-efficacy.
\end{abstract}

\section{Index Terms}

Professional, Self-Efficacy, Work-Related, Industrial Technology

Corresponding author : Allen N. Maroma

allen.maroma@bulsu.edu.ph

- Manuscript received July 22, 2017

- Revised August 11, 2017; Accepted September 1, 2017.

- Date of publication September 30, 2017

(c) The Academic Society of Convergence Science Inc.

2546-1583 $\odot 2017$ IJEMR. Personal use is permitted, but republication/redistribution requires IJEMR permission. 


\section{INTRODUCTION}

Aside from professional knowledge and skills, one important characteristic a teacher must possess is self-efficacy. Gavora [1] defined this as " a selfregulatory, relatively broad, psychological belief system that influences most teacher behavior, including teaching performance." This construct was developed within the context of Albert Bandura's Social Cognitive Theory.

Bandura' theory claims that self-efficacy is composed of two components: efficacy expectations and outcome expectancy. Efficacy expectation refers to the firm belief that an individual possess the ability, knowledge and skills to successfully execute the behavior on actions needed to produce desired results. On the other hand, outcome expectancy is an individual's estimate of the possible consequences of task completion at a self-generated level of performance. This implies that outcome expectancy is a belief that a certain behavior shall eventually result to expectations and high outcome expectancy [1].

In Philippine higher education, the role of Industrial Technology teachers can be considered as a major component to nation building in terms of training the needed manpower requirements of industry locally as well as for international labor markets. Conversely, while they may have acquired some level of status as professionals, it is still considered not within the levels of other professions such as medicine, engineering or law [2].

Taking into account the needs and realities of Industrial Technology instructors and in an effort to progressively improve the curricular offerings of the Bachelor in Industrial Technology program, the teachers' professional image and productivity, this research was thus conceived. The study proposed to analyze how personal and work related factors relate to the professional efficacy of instructors in Industrial Technology in College of Industrial Technology, Bulacan State University.

This investigation aimed to determine the professional self-efficacy levels of Bachelor in Industrial Technology Program teachers and how it correlates to personal and work-related factors.

Specifically, this research undertaking aimed to answer the following questions:

1. How may the demographics of the respondents be described along the following:

1.1 Civil status

1.2 educational qualification

1.3 socio-economic status

1.4 length of service

1.5 membership in professional organizations
2. How may the respondents' working conditions be described along the following constructs:

2.1 Facilities \& equipment

2.2 Program culture;

2.3 Administrative support.

3. How may the professional self-efficacy of the respondents be measured in terms of the following: 3.1 Knowledge improvement;

3.2 Attitude; and

3.3 Practices.

4. Is there a significant correlation between the respondents' work and personal factors with their professional self-efficacy?

This study is anchored on the conceptual framework guided by Albert Bandura's concept of self-efficacy. It is believed that the higher the selfefficacy, the more confident is the individual in his ability to succeed in the performance of one's task. People with high levels of self-efficacy seem to respond to negative feedback with more effort and motivation to overcome the challenge on the other hand, those with low self-efficacy tend to lessen their effort or give up on the completion of the task [3]. Some studies point to three dimensions of teachers' self efficacy: personal efficacy, teaching efficacy and professional efficacy. But for the purpose of this research, analysis and discussion shall focus mainly on teachers' professional efficacy. Figure 1 presents the conceptual model of study, wherein it aims to determine the relationship between dependent variable, professional self-efficacy and the independent variables which are personal and workrelated factors

\section{Independent Dependent Variable}

Variables

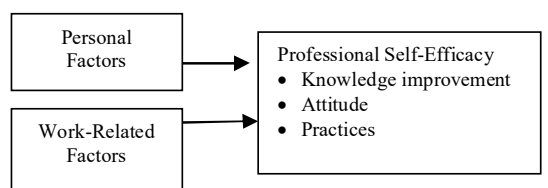

Fig. 1. Conceptual Model of the Study

Vongyuttakrai [4] showed in his study that the strongest indicator of professionalism is competence, on the other hand commitment is the weakest; high level of professionalism and autonomy is demonstrated by teachers who hold doctorate degrees, have undergone advanced studies in industrialized societies, perceive their academic preparation to be adequate, hold memberships in various professional associations, and can articulate the dynamics of their associations; and lastly, 
graduate faculty members' performance in instruction, research and extension are significantly correlated with professionalism.

As asserted by Ornstein [5] mentioned that without continuous updating a teacher's capability tends to become outdated and dry. To keep abreast with the dynamic changes in one's discipline, a teacher needs to: (1) read professional books and journals, (2) attend professional conferences at least two times a year; and (3) attend advanced courses in conjunction with institutional-sponsored programs or programs that have been funded by institutions outside of the university.

Ortigas [6] conducted a study on the effect s of teacher's enhancement program on the self-efficacy levels of Home Economics teachers. Findings revea that the enhancement program effected change and significantly increased efficacy levels of the teacher respondents. In a study by Schwarzer and Hallum [7] they examined the relationships between teachers' perceived self-efficacy, job stress and burnout. The results showed that low self-efficacy among teachers preceded feelings of burnout. Kim, Sihn and Mitchell [8] studied the efficacy beliefs of Korean Mathematics teachers and ascertained the factors that related to efficacy beliefs. They observed that the teaching efficacy beliefs were at variance by levels of education, certification and length of teaching experience. Efficacy beliefs of teachers increase as years of experience increase, efficacy seemed to be highest among the respondents with eleven to fifteen years of teaching experience. The results revealed that there was a notable decline after fifteenth year range, this was attributed to a significant reduction in certification and participation in professional development. Thus, the findings suggest that teaching efficacy may increase with intensified participation in teachers' professional development programs.

\section{Methodology}

This research undertaking made use of the descriptive method of research. Sixty five (65) instructors from the College of Industrial Technology from the Bulacan State University were purposively included as the respondents of this study. The main research instrument was administered to the respondents under the strict supervision of the researchers.

The research adapted the questionnaire developed by Ortigas [2a] which was used to gather information and gauge the personal and work-related factors and the teachers' professional efficacy scale. Indicators of work related factors include physical facilities and equipment, program culture, administrative support and professional organization. Professional efficacy,

in the context of this study, refers to the teachers belief and judgement of their initiative to improve knowledge, attitudes and practices with respect to seeking professional growth through research and extension work, maintenance of high standards in instruction and the observance of the code of conduct.

The set of questions in the instrument utilized a four point response mode of the Likert Scale as follows (SA) Strongly Agree - 4, (A) Agree - 3, (D) Disagree - 2, and (SD) Strongly Disagree - 1.

In the analysis of data, statistical tools include the descriptive statistics, mainly, percentage distribution, mean and standard deviation. These were used describe the components of the personal and workrelated profile of the respondents. To afford an insightful understanding of the outcomes, the following scaled interpretation of each mean was used in the analysis of the levels of perception of the respondents on the work-related factors and the three indicators of teachers' professional efficacy.

\section{Range}

$3.5-4.0(\mathrm{SA})$

$2.5-3.49(\mathrm{~A})$

$1.5-2.49(\mathrm{D})$

$1.0-1.49$ (SD)

\section{Descriptive Ratings}

Very Satisfactory
Satisfactory
Fair
Poor

On the basis of the data that was extracted from the main research instrument, the Spearman Correlation Coefficient was used to determine the relationship between perceived professional efficacy of teachers and personal and work-related factors.

\section{RESUlts AND Discussion}

\section{A. Correlates of Teachers; Professional Self- Efficacy}

The personal and work-related factors as independent variables were correlated to the three indicators of professional self-efficacy levels of the respondents with the use of the Spearman correlation coefficient test. For optimum disclosure, only the variables that were found to be significantly correlated are reflected in the tables. Findings revea that there is no significant relationship between the teachers' perceived professional efficacy and personal-related variables: civil status, age, and monthly income. Administrative support, as workrelated variables was also found to have no significant relation to teachers' professional efficacy.

Table 1 shows that the number of years as a teacher was found to be significantly correlated with knowledge improvement to a low level. This indicates that more mature teachers tend to have more professional efficacy than their younger colleagues in terms of having the initiative to 
continuously maintain high standard of performance by constantly updating their knowledge in their chosen fields of specialization.

Table 1. SignificANT CoRrelates KNOWLEDGE IMPROVEMENT AS AN INDICATOR OF PROFESSIONAL EFFICACY

\begin{tabular}{|c|c|c|c|c|c|c|}
\hline \multirow{3}{*}{$\begin{array}{l}\text { Knowledge } \\
\text { Improvement as } \\
\text { an Indicator of } \\
\text { Professional } \\
\text { Efficacy }\end{array}$} & \multicolumn{6}{|c|}{ Correlates } \\
\hline & \multicolumn{2}{|c|}{$\begin{array}{c}\text { Number of } \\
\text { Years as a } \\
\text { Teacher }\end{array}$} & \multicolumn{2}{|c|}{$\begin{array}{l}\text { Program } \\
\text { Culture }\end{array}$} & \multicolumn{2}{|c|}{$\begin{array}{l}\text { Educational } \\
\text { Attainment }\end{array}$} \\
\hline & $\mathrm{r}$ & $\begin{array}{c}\mathrm{p}- \\
\text { value }\end{array}$ & $\mathrm{r}$ & $\begin{array}{c}\mathrm{p}- \\
\text { value }\end{array}$ & $\mathrm{r}$ & $\begin{array}{c}\mathrm{p}- \\
\text { value }\end{array}$ \\
\hline $\begin{array}{l}\text { 1. Acknowledge } \\
\text { limitations and } \\
\text { make referrals } \\
\text { to more } \\
\text { knowledgeable } \\
\text { persons. } \\
\text { 2.Have ull } \\
\text { knowledge and } \\
\text { understanding } \\
\text { of teachers' } \\
\text { code of ethics. } \\
3 \text {. } \\
\text { Have the } \\
\text { initiative to } \\
\text { continuously } \\
\text { maintain high } \\
\text { standard of } \\
\text { performance by } \\
\text { constantly } \\
\text { upgrading } \\
\text { knowledge in } \\
\text { field of of } \\
\text { specialization. } \\
4 . \text { Have the } \\
\text { desire to } \\
\text { exchange ideas } \\
\text { with colleagues } \\
\text { and superiors } \\
\text { for professional } \\
\text { growth. }\end{array}$ & .192 & .280 & .362 & .000 & .226 & .007 \\
\hline
\end{tabular}

* Significant level at $\mathrm{p}<0.05$

On the variable of work-related factor, the indicator on program culture has shown to be positively correlated with a moderately low level to all parameters of knowledge improvement as an indicator of teachers' professional efficacy except for the item on their understanding of the teacher's code of ethics. The findings suggest that the higher the satisfaction of teachers in their program culture, the higher is their perceived professional limitations in: acknowledging limitations; taking the initiative to continuously maintain high standard of performance and to exchange ideas with colleagues and superiors for professional growth.

Data also shows that the respondents' initiative to continuously maintain high standard of performance by upgrading knowledge is significantly correlated to a moderately low level to educational attainment. This suggests that teachers with higher educational attainment have added initiative in pursuing activities that can lead in the furtherance of their competencies in their field.

Table 2 presents the indicator of attitude for professional efficacy is positively correlated with a low level to administrative support. This indicates that the higher satisfaction of teachers in the support the administration gives to them, would result in the higher likelihood of the teachers in accepting suggestions and constructive criticisms for professional growth and in making due acknowledgement of assistance received from associates.

Table 2. SIGNIFICANT CORRELATES OF ATTITUDE AS AN INDICATOR OF PROFESSIONAL EFFICACY

\begin{tabular}{|c|c|c|c|c|}
\hline \multirow{3}{*}{$\begin{array}{l}\text { Attitude as an } \\
\text { Indicator of } \\
\text { Professional } \\
\text { Efficacy }\end{array}$} & \multicolumn{4}{|c|}{ Correlates } \\
\hline & \multicolumn{2}{|c|}{$\begin{array}{l}\text { Administrative } \\
\text { Support }\end{array}$} & \multicolumn{2}{|c|}{ Program Culture } \\
\hline & $\mathrm{r}$ & $\mathrm{p}$-value & $\mathrm{r}$ & $\mathrm{p}$-value \\
\hline $\begin{array}{l}\text { 1. Accepts } \\
\text { challenging } \\
\text { assignments from } \\
\text { colleagues in } \\
\text { professional } \\
\text { organizations } \\
\text { 2.Professional } \\
\text { organizations } \\
\text { assist in } \\
\text { professional } \\
\text { growth. } \\
\text { 3.Accepts } \\
\text { suggestions and } \\
\text { constructive } \\
\text { criticisms for } \\
\text { professional } \\
\text { growth. } \\
\text { 4. Makes due } \\
\text { acknowledgement } \\
\text { of assistance } \\
\text { received from } \\
\text { associates. }\end{array}$ & .254 & .008 & .348 & .000 \\
\hline & .185 & .025 & & \\
\hline
\end{tabular}

*Significant level at $\mathrm{p}<0.05$

Program Culture is also found to be correlated with a moderate level with attitude for professional efficacy. Findings suggest that the higher perceived satisfaction of the teachers with the program culture would effect to higher rates of acceptance of challenging assignments from colleagues in professional organizations and they would perceive that professional organizations assist in professional growth

Table 3 presents attitude as an indicator of professional efficacy is found to be significantly correlated to professional organization to a low level.

This means that membership in organizations contribute to teachers' frequency in reading books and journals to keep updated on trends and issues in Industrial Technology; communicating regularly 
with officers/members of professional organizations for networking and updates; contribute to research and research publications; and develop a firm understanding of intellectual property rights of colleagues in the profession.

Table 3. Significant Correlates of Practice as an INDICATOR OF PROFESSIONAL EFFICACY

\begin{tabular}{|c|c|c|c|c|c|c|}
\hline \multirow{3}{*}{$\begin{array}{l}\text { Practice as an } \\
\text { Indicator of } \\
\text { Professional Efficacy }\end{array}$} & \multicolumn{6}{|c|}{ Correlates } \\
\hline & \multicolumn{2}{|c|}{$\begin{array}{c}\text { Facilities and } \\
\text { Equipment }\end{array}$} & \multicolumn{2}{|c|}{$\begin{array}{c}\text { Program } \\
\text { Culture }\end{array}$} & \multicolumn{2}{|c|}{$\begin{array}{l}\text { Professional } \\
\text { Organization }\end{array}$} \\
\hline & $\mathrm{r}$ & p-value & $\mathrm{r}$ & p-value & $\mathrm{r}$ & $p$-value \\
\hline $\begin{array}{l}\text { 1. Reading books and } \\
\text { journals to keep } \\
\text { updated on trends } \\
\text { and issues in } \\
\text { Industrial } \\
\text { Technology } \\
\text { 2. Communicating } \\
\text { regularly with } \\
\text { officers/members of } \\
\text { professional } \\
\text { organizations for } \\
\text { networking and } \\
\text { updates. } \\
\text { 3. Develop a firm } \\
\text { understanding of } \\
\text { intellectual property } \\
\text { rights of colleagues } \\
\text { in the profession. } \\
\text { 4.Attending } \\
\text { professional } \\
\text { conferences at least } \\
\text { once a year. } \\
\text { 5.Taking advanced } \\
\text { course through } \\
\text { university sponsored } \\
\text { programs or in- } \\
\text { service programs. } \\
\text { 6. Contributes to } \\
\text { research and research } \\
\text { publications. } \\
\text { 7.Effectively } \\
\text { contributes to } \\
\text { community service } \\
\text { activities. }\end{array}$ & .227 & ...008 & .342 & .0 & .316 & .000 \\
\hline
\end{tabular}

*Significant level at $\mathrm{p}<0.05$

Program culture is also found to be positively correlated to attitude as an indicator of professional efficacy to a moderately low level. This suggests that satisfaction in program culture contribute to the teachers' developing a firm understanding of intellectual property rights of colleagues in the profession; and attending professional conferences a least once a year. The table further shows that facilities \& equipment is also positively correlated to attitude as an indicator of professional efficacy to a low level. This signifies that satisfaction on facilities and equipment results to the teachers to engage in taking advanced course through university sponsored programs or in-service programs; and contributes to research and research publications.

\section{CONClusions AND \\ RECOMMENDATIONS}

Based on the salient findings of the study, the following conclusions were made by the researchers: The respondents perceive facilities and equipment, program culture, administrative support and membership in organizations as satisfactory. Professional efficacy levels among the respondents, generally, have moderately high professional efficacy levels in all the indicators of this variable. Work related variables are predominantly significantly related to professional efficacy rather than personal-related variables. Program culture has positive significant correlation with knowledge improvement as an indicator of professional efficacy. Administrative support and program culture have positive significant correlation with attitude as an indicator of professional efficacy. Facilities \& equipment, program culture and professional organizations have positive significant correlation with practice as an indicator of professional efficacy. Personal-related factors, namely, civil status, age, and monthly income have no significant relation to the respondents' professional efficacy. On the other hand, number of years as a teacher; and educational attainment has positive correlation with professional efficacy.

In the light of the conclusions extracted, the researchers offer the following recommendations:

To further enhance the professional efficacy levels of teachers, they may be encouraged to pursue further studies and finish their respective graduate degrees. Opportunities for scholarships, trainings and conferences may be offered by the university to further entice teachers to engage in worthwhile academic undertakings. Funding for enhancement of teachers qualifications must be readily made available to teachers and shorten the process of applying for subsidy. Awareness and access to memberships in professional organizations may be enhanced through strengthened information dissemination. Constant correspondence between members and professional organizations may be fostered through the web

\section{REFERENCES}

[1] Gavora, P. (2010). Slovak pre-service teacher self-efficacy: Theoretical and research considerations. The New Educational Review, 21(2), 17-30.

[2] Ortigas M.E., et.al (2015). Personal and work related correlates of professional self-efficacy of teachers in home economics and TLE programs. The Journal of Philippine 
Association for Technology in Home Economics in State Colleges and Universities, Inc. 37-47

[3] Davis, K., \& Newstrom, J. W. (1989). Human behavior at work: Organizational behavior. McGraw-Hill.

[4] Vongyuttakrai, S.A. (1990). Sources of professionalism, professionalism and performance of graduate faculty members in selected teacher-training institution. Unpublished Doctoral Dissertation. College of Education University of the Philippines Diliman, Quezon City.

[5] Ornstein, A. C. (1995). Strategies for effective teaching WCB/McGraw-Hill.

[6] Ortigas, M.A. and E.A. Orlina (2000). Effects of teachers nhancement program on self home economics teachers in Iloilo City. The Journal of Philippine Association for Home Economics in State Colleges and Universities 1(1), 1-8

[7] Schwarzer, R., \& Hallum, S. (2008). Perceived teache self-efficacy as a predictor of job stress and burnou: Mediation analyses. Applied psychology, 57(s1), 152-171.

[8] Kim, R., H.G. Sihn and R. Mitchell. (2004). South Korean elementary teachers' mathematics teaching efficacy beliefs: implications for educational policy research. Internation
Scientific Publications and Consulting Services (ISPACS).

9] Ortigas M.E. (2000). Effects of teachers' enhancemen

program on selfefficacy of public secondary bement program on self-efin in Dissertation. College of Home Economics. University of the Philippines Diliman, Quezon City.
메모 포함[성2]: 구글 미검색

메모 포함[성3]: 구글 미검색

메모 포함[성4]: 구글 미검색 